IN brief

\section{cDNA is patentable, but not genes}

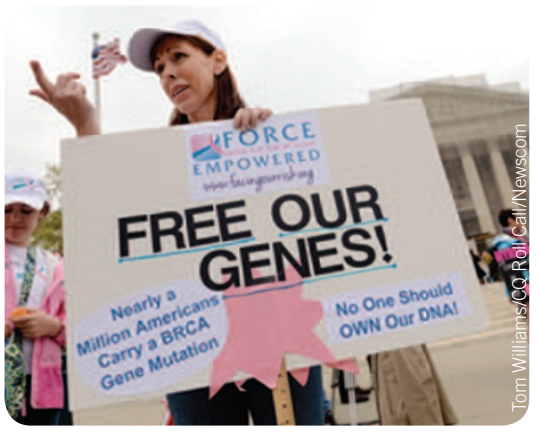

The fight over $B R C A$ genes is now over

A unanimous US Supreme Court ruled on June 13 that a naturally occurring DNA segment is a product of nature and not eligible for patenting merely because it has been isolated. But cDNA, because it is not naturally occurring, may be the subject of patent claims. The mixed outcome ends the long-running patent case brought against Myriad Genetics of Salt Lake City, Utah. The Supreme Court accepted the case after a contrary ruling by the US Court of Appeals for the Federal Circuit, which had found both isolated DNA and cDNA claims patent eligible (Nat. Biotechnol. 29, 771, 2011). Myriad is the developer of a test for BRCA1 and BRCA2 gene mutations, which it uses to assess the risk of breast and ovarian cancer. "Myriad's claims are not saved by the fact that isolating DNA from the human genome severs the chemical bonds that bind gene molecules together," the court wrote, or by the argument that the US Patent and Trademark Office's past practice of awarding gene patents is entitled to deference. Further, the court noted, the case did not involve method claims, patents on new applications of knowledge about the BRCA1 and $B R C A 2$ genes, or the patentability of DNA in which the order of the naturally occurring nucleotides has been artificially altered. Myriad president and CEO, Peter Meldrum, wrote in a press release, "We believe the Court appropriately upheld our claims on cDNA, and underscored the patent eligibility of our method claims, ensuring strong intellectual property protection for our BRACAnalysis test moving forward." The mixed ruling may have only a minimal effect on Myriad's business, given its announced plans to fold BRCA testing into a new product, myRisk Hereditary Cancer, a 25-gene panel that identifies genetic predisposition risk to six different cancers, including breast and ovarian, this fall.
For Thermo Fisher, the deal represents a decision to buy sequencing assets instead of building the business up through internal $\mathrm{R} \& \mathrm{D}$, and continues an ongoing industry consolidation. "We thought that it was a market best served by two major industry participants," says Casper, not more. "We had always chosen not to be a third participant, other than as a supplier of some reagents and supplies."

Other next-generation instrument developers are shifting their strategies. For example, recognizing it was lagging behind the next-generation sequencing market leaders, Basel-based Roche in April announced that it is reorganizing its Applied Science business, effectively cannibalizing its 454 resequencing business and ending its collaboration with IBM in nanopore sequencing. Although 454 was first to commercialize a long-read resequencing system, it was overtaken by Illumina and Ion Torrent. "This is a market where a fast follower with a unique or superior product certainly can leapfrog a first entrant," says Banerjee. "Roche found itself with a technology with a long-read attribute but eroding differentiation, competing in a market that is rapidly moving towards a more distributed market, lower cost and higher performance, at a scale at which their legacy technology cannot compete."
Genomics companies are also taking steps to focus on workflow more so than hardware, both on the front end with respect to sample and library prep and also on the back end of sequencing. The most recent example is Qiagen's April 2013 acquisition of Ingenuity Systems, in Redwood City, California, which increased the genomics data analysis capabilities of the Venlo, The Netherlands-based provider of sample and assay prep technologies. "Qiagen has always maintained that it wants to focus on applications, on the applied markets such as diagnostics," Quirk says, rather than supplying ultra highthroughput machines to genome centers, a mainstay of Illumina and Life Technologies. "They try to win on workflow."

That said, few companies in tools or diagnostics have truly made the transition from one into the other, says Quirk. But with the research market hindered by the global slowdown in basic research funding and many leading suppliers experiencing only low single-digit revenue growth as a result, and with opportunities opening up in diagnostics, there's ample reason for research tools providers like Illumina, Qiagen, Life Technologies and Thermo Fisher itself to look downstream towards clinical applications.

Mark Ratner Cambridge, Massachusetts

\section{IN their words}

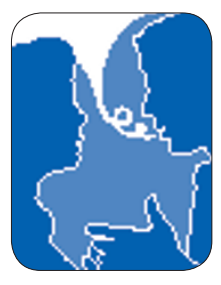

"What matters to me is I have three customers who don't want GM wheat: Japan, South Korea and Taiwan," said Walter Powell president of the Oregon Wheat Growers Association. In May, glyphosate-resistant wheat was found in a 125 -acre field in the state. GM wheat was last field tested (it was never marketed) by Monsanto in Oregon and 15 other states in 2001. (The Oregonian 9 June 2013)

"Biotech is both the worst business in the world and the best business in the world," said Rajiv Kaul, portfolio manager of Fidelity Investments Select Biotechnology Portfolio, in Boston, discussing the biotech stocks' recent 'bull run'. (Reuters, 28 May 2013)

"If I have a million people walking around town with their genetic data, it creates a little bit of chaos." Anne Wojcicki, founder of 23andme, explaining to the Big Data in Biomedicine Conference at Stanford University her company's goal of collecting a million genomes. (Biolt World, 23 May 2013)

"I had never in my life witnessed something like that. I have never seen [my son] so happy in his entire life as when he finished that song and looked out at the crowd." Christina Murphy of Holton, KA, talks of her son's progress on an experimental therapy, arbaclofen for Fragile $\mathrm{X}$ and autism. Drug maker, Seaside Therapeutics, announced in June that the drug would no longer be available, as it failed to meet its endpoint in trials. (New York Times, 6 June 2013)

"The people deserve to know what they are putting into their bodies, and this setback only strengthens my resolve to see this bill become law." New York assemblywoman Linda Rosenthal, on the defeat of her bill to require labeling of GM food. (The New York Daily News, 3 June 2013) 